[DOI: 10.24214/jecet.A.10.4.59094.]

Jaurnal of Enviranmental Science, Computer Science and

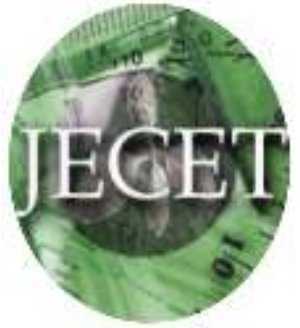
Engineering \& Technology

An International Peer Review E-3 Journal of Sciences and Technology

Available online at www.jecet.org

Section A: Environmental Science

Research Article

\title{
Influence of Organic Amendments (Cow dung, wood ash and chicken dung) on the Yield of Baselle (Basella alba).
}

\author{
Okoko Olongo Alphonse *; Shadari Salumu A.; Mubwana Shabani C. \\ University of Kindu, Faculty of Agronomic Sciences, DR Congo.
}

Received: 20 August 2021; Revised: 18 September 2021; Accepted: 21 October 2021

\begin{abstract}
The general objective of this work was to study the influence of organic amendments (cow dung, wood ash and chicken droppings) on the yield of basella (Basella alba).To achieve this, a randomized complete block system comprising four repetitions and four treatments was set up. In fact, the highest and best yield was obtained with treatment three (chicken manure) which gave 18.3t / ha.Therefore, we recommend that peasants and Farmers use chicken manure in order to increase the yield of the baselle.
\end{abstract}

Keywords: Influence, amendments, Baselle, Yield.

\section{INTRODUCTION}

Some regions of the DR Congo are better suited than others for vegetable production. The hot and humid diet that characterizes these in certain seasons makes success in vegetable cultivation uncertain, the most popular of which are in particular tomatoes, eggplants, shallots, cabbages, carrots, cucurbits, spinach, amaranths etc. ${ }^{[1]}$.

The consumption of these various agricultural products provides the human body with plant proteins, energy, mineral salts, vitamins (A, D, E and $\mathrm{K}$ ); reason why this vegetable is appreciated by children, pregnant women and adult men. They are also a source of income. Unfortunately the cultivation of vegetables is not always well practiced and is not cultivated in large areas compared to other food crops. This is due to the farmers' ignorance of appropriate vegetable growing techniques. However, growing vegetables does not require large means but will and expertise, ${ }^{[2]}$.

The Province of Maniema in general and the town of Kindu in particular, is experiencing a serious problem relating to the production and consumption of leafy vegetables, including baselle. This 
vegetable provides variable proportions of nutrients essential for maintaining the human body in good health. But this culture is not produced in large quantities in the town of Kindu and its surroundings.

Whatever the multiple importance of the plant, this crop experiences many difficulties which essentially lead to a drop in yield, including:

- Failure to respect adequate cultivation techniques linked to the good production of the plant;

- The insufficiency of improved varieties (resistant and productive) encountered in the environment;

- The attacks of diseases and pests on the crop grown in small area;

In carrying out this study, the general objective is to control the influence of organic amendments on the yield of baselle ${ }^{[3]}$.

\subsection{With specific objectives:}

- Determine among the organic amendments used, which one can give a better yield in leaf of the baselle;

- Check the behavior of the baselle vis-à-vis these different types of organic amendments used.

In order to achieve these objectives, the following assumptions have been made:

$\checkmark$ Among the organic amendments used; chicken manure could promote good baselle growth and yield;

$\checkmark$ The behaviour of the base in the face of these different types of amendments would be very interesting from the point of view of growth and increase in leaf yields.

\section{MATERIAL AND METHODS}

In this test, spinach seeds of the variety rubla were used. This was obtained locally in an agricultural veterinary pharmacy of Catholic priests.

\subsection{The main characteristics of this variety are:}

\begin{tabular}{|l|l|}
\hline Species: Baselle rubra & Growth type: determined \\
\hline Leaf and stem color: red & Height at maturity: $2 \mathrm{~m}$ \\
\hline $\begin{array}{l}\text { Leaf shape: whole, round, alternating } \\
\text { and turgid }\end{array}$ & Flowering days: 60 to 75 \\
\hline Flower color: purple & Fruit color: purple \\
\hline Seed size: small & Seed shape: spherical \\
\hline Integument color: black & $\begin{array}{l}\text { Yield: } 30 \text { to } 50 \mathrm{~T} / \text { ha of leaves } \\
\text { (in a controlled environment) }\end{array}$ \\
\hline In a real environment $: 20$ to $30 \mathrm{~T} / \mathrm{ha}$ & Duration to maturity: 3 months \\
\hline Lodging resistance: fragile & To diseases: Tolerant, ${ }^{[4]} \cdot$ \\
\hline
\end{tabular}

The experiment had a randomized full block device with four repeats and four treatments made up of the different types of organic amendments. 


\section{RESULTS AND DISCUSSION}

\subsection{Influence of organic amendments on baselle growth}

Table 1: Summary of vegetative parameters observed on baselle feet.

\begin{tabular}{|l|l|l|l|l|}
\hline Treatments & $\begin{array}{l}\text { 7-Day recovery } \\
\text { rate }(\%)\end{array}$ & $\begin{array}{l}\text { Height of plants } \\
\text { at } \mathbf{4 5} \text { days }(\mathbf{c m})\end{array}$ & $\begin{array}{l}\text { leaf area at 45 } \\
\left.\text { days } \mathbf{( c m}^{2}\right)\end{array}$ & $\begin{array}{l}\text { Number of days } \\
\text { at flowering }\end{array}$ \\
\hline Witness & 64 & 30 & 73 & 40 \\
\hline Cow boils & 96 & 51 & 114 & 45 \\
\hline Wood ash & 96 & 50 & 95 & 45 \\
\hline Chicken dung & 98 & 41 & 79 & 43 \\
\hline Mean & 89 & 41 & 90 & 43 \\
\hline C.V $(\%)$ & 6 & 0,7 & 90 & 44 \\
\hline Ppds & 0,5 & 0,8 & 2,2 & 1,9 \\
\hline
\end{tabular}

C.V = Coefficient of variation;

ppds $=$ Smallest significant difference

3.2. Recovery rate at 07 days (\%): It emerges from this table that, the average recovery rate at 07 days after transplanting in all the treatments was $89 \%$, while the highest recovery rate was $98 \%$ observed in treatment three (chicken droppings). ); while, the lowest recovery rate was $64 \%$ at the control treatment (unfertilized land) and the intermediate recovery rate was $96 \%$ observed respectively at treatments one and two (cow dung and wood ash) ${ }^{[5]}$.

This table shows that the height of the plant taken at 45 days varied from $30 \mathrm{~cm}$ for the control treatment, $51 \mathrm{~cm}$ for one (cow dung), $50 \mathrm{~cm}$ for two (wood ash) and $41 \mathrm{~cm}$ for three (chicken droppings). ). The average height was $41 \mathrm{~cm}$ for all the treatments applied.

It emerges from this table that, the leaf area of the plants at 45 days after transplanting that the leaf area varied from $73 \mathrm{~cm}^{2}$ for control treatment (unfertilized land), from $119 \mathrm{~cm} 2$ to treatment one (cow dung), from $95 \mathrm{~cm} 2$ for treatment two (wood ash) and $79 \mathrm{~cm} 2$ for treatment three (chicken manure). The average leaf area was $90 \mathrm{~cm} 2$ for all treatments applied. In addition, the results of the analysis of variance prove that there is a significant difference between the different treatments and the ppds test was $2.2 \mathrm{~cm}^{2}$.

However, Kalondji ${ }^{[6]}$ explains that once if the doses of fertilizer are respected and the maintenance care brought to the baselle, the plant gives large and numerous leaves on an orderly phyllotaxis and finally the production increases to the plant. .

This table proves that, the number of days to flowering of the plant taken at 45 days varied from 40 days for the control treatment (unfertilized land), from 45 days for treatment one (cow dung), from 45 days for treatment two (wood ash) and 43 days for treatment three (chicken manure). The average number of days to flowering was 43 days for all treatments applied. Analysis of variance shows that there was a significant difference between the treatments and the ppds test was 1.9 days. According to our own sources, it was observed that the number of days to flowering was delayed due to regular pinching of the apical and axillary buds and the abundance of rains. 


\subsection{The influence of organic amendments on baselle production}

Table 2: Summary of the production parameters observed on the feet of the cultivated baselle Misenge.

\begin{tabular}{|l|l|l|l|}
\hline Treatments & $\begin{array}{l}\text { Number of leaves / } \\
\text { plant at harvest }\end{array}$ & $\begin{array}{l}\text { Leaf weight at } \\
\text { harvest }(\mathbf{k g})\end{array}$ & $\begin{array}{l}\text { Yield in tonnes } \\
\text { per hectare } \\
\text { (t / ha) }\end{array}$ \\
\hline Witness & 42 & 0,05 & 8,3 \\
\hline Cow dung & 78 & 0,10 & 16,6 \\
\hline Wood ash & 65 & 0,07 & 11,6 \\
\hline Chicken dung & 89 & 0,11 & 18,3 \\
\hline Mean & 69 & 0,08 & 13,7 \\
\hline C.V (\%) & 3,6 & 2,6 & 3,6 \\
\hline ppds & 11,2 & 0,03 & 1,1 \\
\hline
\end{tabular}

3.4.Number of leaves per plant at harvest: Reading this table shows that, the average leaf count per plant across all treatments was 69 leaves; while, the highest number of leaves was 89 leaves obtained in treatment three (chicken manure); on the other hand, the lowest number of leaves was 42 leaves obtained with the control treatment (unfertilized land); on the other hand, the number of intermediate leaves was recorded in treatment one (cow dung) with 78 leaves and in treatment two (wood ash) with 65 leaves.

Effect, analysis of variance shows that there was a significant difference between the treatments and ppds test was 11.2 leaves.

3.5.Leaf weight at harvest in (kg): Reading this table shows that the average leaf weight at harvest in all treatments was $0.08 \mathrm{~kg}$; while, the highest leaf weight at harvest was $0.11 \mathrm{~kg}$ obtained in treatment three (chicken manure); on the other hand, the lowest leaf weight at harvest was $0.05 \mathrm{~kg}$ obtained with the control treatment (unfertilized land); moreover, the weight of the intermediate sheets was recorded in treatment one (cow dung) with $0.10 \mathrm{~kg}$ and in treatment two (wood ash) with $0.07 \mathrm{~kg}$.

Effect, analysis of variance shows that there was a significant difference between the treatments and ppds test was $0.03 \mathrm{~kg}$.

According to Baboy ${ }^{[7,8,]}$ and Emongo ${ }^{[9]}$ inform that the number of leaves of the baselle and the weight of this one depend on the organic fertilization provided and especially on the quantity of nitrogen present in the soil favored vegetative growth which even constitutes the useful product thereof.

3.6.Yield in Tons per hectare ( $\mathbf{T} / \mathbf{h a}$ ): The result of this table shows that the average yield in all the treatments was $13.7 \mathrm{t} / \mathrm{ha}$; while, the highest yield was observed in treatment three (chicken manure) with $18.3 \mathrm{t} / \mathrm{ha}$; on the other hand, the lowest yield was $8.3 \mathrm{t} /$ ha obtained with the control treatment (unfertilized land). However, the intermediate yield was 16.6t / ha for treatment one (cow dung) and 11.6t / ha for treatment two (wood ash). 
The ANOVA reveals that there is a significant difference between the different treatments used and the ppds test was $1.1 \mathrm{t} /$ ha.

\section{CONCLUSION}

The general objective of the present study was to carry out research on the influence of organic amendments (cow dung, wood ash and chicken dung) on the productivity of the baselle in Misenge in the town of Kindu. To achieve this, a device in randomized complete blocks comprising 4 repetitions of 4 treatments made up of the different organic amendments was set up.In fact, the highest and best yield was obtained with treatment three (chicken manure) which gave 18.3t / ha.Therefore, we recommend that peasants and Farmers use chicken manure in order to increase the yield of the baselle.

\section{REFERENCES}

1. Anonyme, Memento de l'Agronome, édition Sebaspool, Paris Bruxelles, 1992.

2. Anonyme, Manuel de vulgarisation technique agricole, culture vivrière C.I.C.R BUKAVU/RDC, 2008.

3. FAO, Fiche technique des cultures maraichères dans les tropiques, 2010.

4. Anonyme, INADES, quelques techniques de cultures des légumes en RDC, 2012.

5. Mobambo,Méthodologie de la Recherche Scientifique, cours inédit Université de Kindu,2010.

6. Kalondji, Phytotrophologie et fertilisation, cours inédit, Université de Kindu, 2010.

7. L.Baboy, Systématique des plantes cultivées, cours inédit, Université de Kindu,2010.

8. L.Baboy, Phytopathologie spéciale et zoologie agricole spéciale, cours inédit Université de Kindu, 2011.

9. Emongo, Cultures maraichères et fruitières, cours inédit, Université de Kindu, 2018.

* Corresponding Author: Okoko Olongo Alphonse

University of Kindu, Faculty of Agronomic Sciences, DR Congo

Online date of publication: 25.10 .2021 